width along much of both coasts and in the numerous river valleys. The interior of the island is a plateau with large areas covered by barrens and sphagnum bogs. In passing eastward from New Brunswick to Nova Scotia the flora becomes distinctly poorer, many species dropping out and few new ones appearing. Cape Breton with a smaller area than the rest of the province and forming its northeastern limit shows a further decrease, although a comparatively large number of forms are known from the island that do not occur on the mainland, while others grow more luxuriantly there, even at the extreme north. Among the former. may be mentioned Samolus floribundus H.B.K., Peramium Menziesii (Lindl.) Morong, Parnassia parviflora DC. and Galium kamtschaticum Steller; among the latter $C y$ pripedium regince Walt., Caltha palustris L., Anemone canadensis L., Blephariglottis blephariglottis (Willd.) Rydb., Vagnera stellata (L.) Morong and Rubus Chamomorus L. The dwarf mistletoe, Razoumofskya pusilla (Peck) Kuntze, apparently of wide distribution in northern Nova Scotia, extends at least fifty miles up the west coast of the island. The ferns are also noteworthy. All the common and a majority of the rarer species of the mainland grow at least as well in Cape Breton, together with two additional species, Dryopteris Felix-mas (L.) Schott and Polystichum lonchitis (L.) Roth., the former widely distributed, but the latter known only from two widely separated localities.

The third paper, by Le Roy Abrams, was on 'Notes on the Flora of Southern California.' After speaking briefly of the topography and general climatic conditions of southern California Mr. Abrams called attention to the extreme variation in the flora and exhibited a series of specimens illustrating the coastal and mountain floras. Among these specimens were three of his recently described new species: Cheiranthus suffrutescens, Heuchera elegans and Godetia Dudleyana.

Other especially interesting plants exhibited were Romneya trichocalyx Eastw., Quercus Engelmanni Greene and Calochortus Catalince Wats.

\section{DISCUSSION AND CORRESPONDENOE.}

THE NOMENCLATURE OF PHYSIOGRAPHY.

To the Editor of Science: I regret very much that the technical nomenclature of the comparatively new science of physiographic geology does not suit Dr. Eastman, of Harvard.

It is essential to ultimately possess a descriptive name for every topographic form. This is a difficult task, and one, in which a field worker, like myself, who seldom has the leisure or opportunity to devote to closet study, finds most difficult, but we do the best we can, and some people manage to understand us.

If I am not mistaken, the science of paleontology, which is indebted to Professor Eastman for his editorial and linguistic assistance, has been floundering for over a century in the throes of an obscure and specialized nomenclature which may be as unintelligible to the physical geographer as the verbiage of the latter seems to Professor Eastman.

It is my opinion, founded on some experience, that language is only an instrument for recording ideas, and that so long as the work is accomplished, the kind or character of the tool is irrelevant. No one appreciates more than I the importance of simple English to good literary form; but I think Professor Eastman is wasting words, ScIEncE's useful space, and myself and most valuable time, in discussing an elementary lack of literary style, weakness inherent in most men except a few rare literary geniuses, whom, so far as I am aware, have not been noted for their acumen in scientific research, or even in scientific statement.

Rовт. T. HILL.

a PECUliar habit OF THE BADGER.

ONLY now, in reviewing the classic work of Dr. Elliot Coues on 'Fur Bearing Animals,' * have I been brought face to face with his statement regarding a peculiar habit of the badger. Otherwise, the information here given would have been made public long ago.

On p. 288 of that volume he quotes Audu-

* U. S. Geol. Surv., Hayden. Misc. Pub., VIII., 1877. 